\title{
BEST PRACTICE METHODS FOR ESTIMATING SUSTAINABLE LONG-TERM VALUE FOR LENDING PURPOSE
}

\author{
Carolina Volosatîi*, ORCID ID: 0000-0002-2306-7211, \\ Svetlana Albu, ORCID ID: 0000-0002-8648-950X \\ Universitatea Tehnică a Moldovei, str. Ștefan cel Mare 68, or. Chișinău, Republica Moldova \\ *Corresponding author: Carolina Volosatîi, carolina.volosatii@emi.utm.md
}

Received: 12. 16. 2021

Accepted: 01. 28. 2022

\begin{abstract}
Mortgage lending creates risks for consumers who resort to loans as well as for credit institutions that make lending decisions. One way to ensure that the potential risks associated with mortgage lending are properly managed is through the value and price of the mortgaged object. This article refers to the new requirements of the European Banking Authority, to determine a prudential value different from the market value as the security for a credit exposure, which takes into account the long-term sustainability aspects of real estate - Sustainable long term value (LTV-S or MLV). Value, which should become a credit risk management tool, and which would provide some protection over time.
\end{abstract}

Keywords: real estate, credit risk, market value, mortgage lending value, valuation, sustainability.

Rezumat. Creditul ipotecar generează riscuri pentru consumatorii care recurg la împrumuturi precum și pentru instituțiile de credit care iau decizii de creditare. 0 modalitate de asigurare că riscurile potențiale asociate creditării ipotecare sunt gestionate în mod adecvat îl reprezintă valoarea și prețul obiectului ipotecat. Prezentul articol se referă la noile prevederi ale Autorităților europene de supraveghere bancară și anume estimarea în scop de garantare a împrumutului a unei valori prudențiale diferite de cea de piață, care ia în considerare aspectele de durabilitate pe termen lung a proprietății imobiliare - Valoarea sustenabilă pe termen lung (LTV-S sau MLV). Valoare, care ar trebui să devină un instrument de gestionare al riscului de credit și care ar oferi o anumită protecție în timp.

Cuvinte cheie: bun imobil, risc de credit, valoare de piață, valoare ipotecară, evaluare, sustenabilitate.

\section{Introducere}

Estimarea obiectivă a valorii bunului imobil - reprezintă fiabilitatea împrumutului pentru toți participanții pieței: stat, creditori, debitori, investitori. [1, p. 56].

După criza financiară post globală, autoritățile de reglementare și alte părți interesate acordă mai multă atenție evaluării bunurilor imobile în caz de creditare ipotecară.

Astfel, odată cu introducerea cadrului Basel III, în ceea ce privește măsurarea capitalului și standardele de capital, autoritățile europene de supraveghere bancară, recunosc 
o nouă definiție privind valoarea proprietății - o definiție bazată pe principii prudențiale și care trebuia implementată de UE/EBA în 2020. Procesul de implementare însă fost perturbat de pandemia COVID-19, ceea ce a condus la amânarea acesteia.

Pe lângă Valoarea de piață Autoritățile Europene prin Regulamentele și Directivele elaborate acordă o atenție deosebită Valorii sustenabile pe termen lung, care se consideră că ar trebui să joace un rol central în practica evaluărilor în scop de garantare a împrumuturilor.

\section{Conceptul de valoare pe termen lung}

Până în anul 2017 autoritățile de reglementare, permit 2 definiții ale valorii proprietății în caz de garantare a împrumutului. Articolul 4 din Regulamentul privind cerințele de capital (CRR) definește drept baza de evaluare - valoarea ipotecară (mortagage lending value) și valoarea de piață (market value) pentru prima dată într-un cadru UE. Articolul respectiv joacă un rol central în practica evaluărilor în scopuri de garantare a împrumuturilor.

Valoarea ipotecară (MLV) conform art. 4 par. 74 al Regulamentului reprezintă „valoarea bunurilor imobile stabilită printr-o evaluare prudentă a valorii de piață viitoare a bunurilor, ținând seama de aspectele sustenabile pe termen lung legate de bunuri, de condițiile de piață normale și locale, de utilizarea curentă și de eventualele utilizări alternative ale bunurilor." [2].

În anul 2017, Basel III a introdus o nouă definiție privind valoarea proprietății imobiliare în scop de garantare a creditului ipotecar, bazat pe principii prudențiale - Valoarea prudentă sau valoarea sustenabilă pe termen lung (Long-Term SustainableValue -LTV-S) definiția se bazează pe același concept ca Valoarea ipotecară (MLV). De altfel, în majoritatea surselor acestea sunt echivalate.

Valoarea sustenabilă pe termen lung (LTSV) - valoarea unui bun imobil determinată printr-o evaluare prudentă a vandabilității viitoare a proprietății, luând în considerare aspectele de durabilitate pe termen lung ale proprietății, condițiile de piață normale și locale, utilizarea curentă a acesteia și utilizările alternative adecvate ale proprietății [3].

Valoarea sustenabilă pe termen lung (LTSV) - constituie un concept științific metodologic, obiectivul căreia este de a depăși distorsiunile de aplicare a valorii ipotecare (MLV) care a fost introdusă prin Directiva 2006/48/CE5 și apoi cu Regulamentul (UE) 575/ 20136 și a evidențiat neajunsuri în faza de aplicare, întrucât nu există abordări generale asociate cu nevoile specifice ale creditorilor. Prin urmare LTSV ar trebui să fie funcțională în identificarea valorii celei mai probabile pe termen lung, în scopul garantării împrumuturilor [3].

Majoritatea țărilor Europene nu utilizează conceptul de valoare pe termen lung MLV sau LTSV, astfel, acestea nu sunt bine dezvoltate și nu există o metodologie unică de estimare.

Reieșind din ultimele activități ale diferitor organisme Europene în domeniul evaluării pentru garantarea împrumutului se așteaptă evoluții semnificative în acest domeniu în diferite țări in viitorul apropiat. În prezenta lucrare cu referire la valoare prudentă pe termen lung se va utiliza noțiunea de valoarea ipotecară.

\section{Deosebirea între Valoarea de piață și Valoarea ipotecară (MLV sau LTSV).}

Valoarea ipotecară se deosebește de valoarea de piață prin faptul că prima reflectă valoarea proprietății pentru o perioada lungă de timp, pe când ultima - valoarea proprietății la data evaluării.

Valoarea de ipotecară nu trebuie confundată cu Valoarea de piață sau valoarea de lichidare. Ea nu se bazează pe corelația cerere-ofertă la data evaluării, precum valoarea de 
piață nici nu corespunde situației de vânzare forțată a bunului la data evaluării ca în cazul valorii de lichidare.

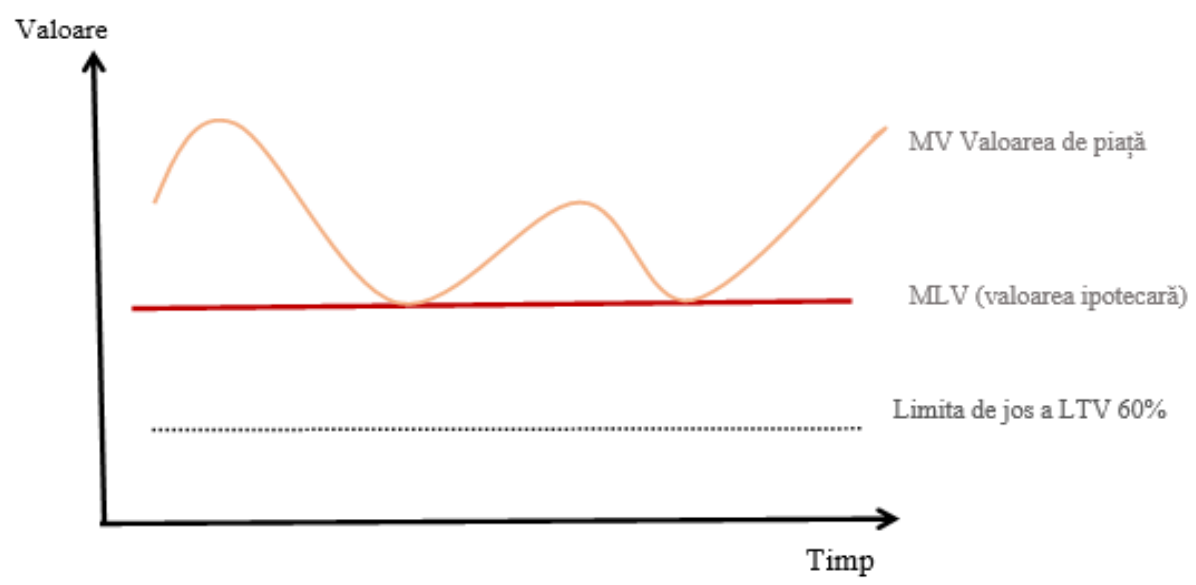

Figura 1. Diferența între valoarea de piață și valoarea ipotecară. Sursa : Întocmit de autor in baza [4, 5].

Astfel, dacă încercăm să analizăm mai detaliat problema, devine clar că valoarea ipotecară este un tip independent de valoare care reprezintă cea mai probabilă sumă de bani pe care o instituție de credit o poate primi ca urmare a vânzării garanției în orice moment al perioadei de creditare, luând în considerare scăderea valorii de piață odată cu sporirea riscurilor posibile, costurilor juridice și a cheltuielilor de realizare.

Considerarea unei perspective pe termen lung, acordarea creditelor pe baza valorii ipotecare, calculată printr-o metodă conservatoare asigură părților semnatare o rată a creditelor neperformante mult mai scăzută decât contractele bazate pe valoarea de piață. În al doilea rând, din cauza diferenței dintre valoarea de piață și valoarea ipotecară, fazele ciclului de piață devin mult mai transparente.

Valoarea ipotecară joacă un rol de nivelare a extremelor, mai ales pe piețele foarte volatile, asigurând atenuarea exagerărilor în ambele direcții și neafectarea directă a acțiunilor participanților pe piață. De asemenea, reflectă natura investițiilor imobiliare ca investiții pe termen lung [6, p. 36].

Valoarea unei proprietăți poate scădea considerabil din cauza fluctuațiilor de pe piață. De asemenea, fluxul stabil de numerar generat pe o perioadă determinată a creditului poate să însemne că riscul de non performanță pentru o anumită proprietate imobiliară poate fi contracarat și că proprietatea respectivă poate să supraviețuiască unei crize a pieței imobiliare, fără să genereze pierderi pentru bancă.

\section{Practica Germaniei în determinarea valorii ipotecare}

Cercetările efectuate legate de metodele de estimare a valorii ipotecare pentru garantarea creditului ipotecare ne arată că, una dintre cele mai bine stabilite seturi de linii pentru determinarea valorii ipotecare o are Germania.

În Germania creditul ipotecar se bazează pe o metodologie de determinare a valorii sigure ipotecare care datează de peste 100 de ani. Metodologia își are originile în Legea Băncilor Ipotecare din 1900 înlocuită în 2005 cu legea obligațiunilor ipotecare (legea Pfandbrief). Valoarea de garantare a creditului ipotecar a fost definită ca valoarea pe care o proprietate imobiliară o poate avea în orice moment pe durata creditului, dacă aceasta s-ar vinde într-o tranzacție nepărtinitoare pe piața liberă, fără exercitarea vreunei presiuni sau a 
unor măsuri corective. De asemenea în Germania sunt definite proceduri speciale de calcul a acestei valori (Regulamentul BelwertV) în anul 2006.

Legea obligațiunilor ipotecare în cadrul secțiunii 16 definește de asemenea valoarea ipotecară, ca o valoare care nu poate depăși Valoarea de piață calculată în mod transparent și în conformitate cu o metodă de evaluare recunoscută [5].

Reglementările germane prevăd că estimarea MLV nu trebuie realizată folosind o abordare derivată care necesită estimarea preliminară a valorii de piață a proprietății și aplicarea ulterioară a unui coeficient de reducere - abordare utilizată de instituțiile de credit, însă are în vedere determinarea unei valori independente. Cu toate acestea au existat și critici ale acestei abordări datorită unor constrângeri operaționale [7 - 9].

În conformitate cu reglementările germane estimarea valorii ipotecare se va efectua prin metode conservative (Figura 2) ținându-se cont de următoarele:

$\begin{array}{ll}\checkmark & \text { Proprietățile trebuie inspectate } \\ \checkmark & \text { Valoarea ipotecară nu trebuie să fie mai mare decât valoarea de piață } \\ \checkmark & \text { Proprietatea poate fi utilizată de către terți } \\ \checkmark & \text { Datele de piață obiective și comparabile } \\ \checkmark & \text { Caracteristicile pe termen lung (sustenabile) ale proprietății } \\ \checkmark & \text { Utilizarea curentă } \\ \checkmark & \text { Vandabilitatea proprietății (alte utilizări potențiale) } \\ \checkmark & \text { Transparența evaluării } \\ \checkmark & \text { Independența evaluării [5, } 6,10,11] .\end{array}$

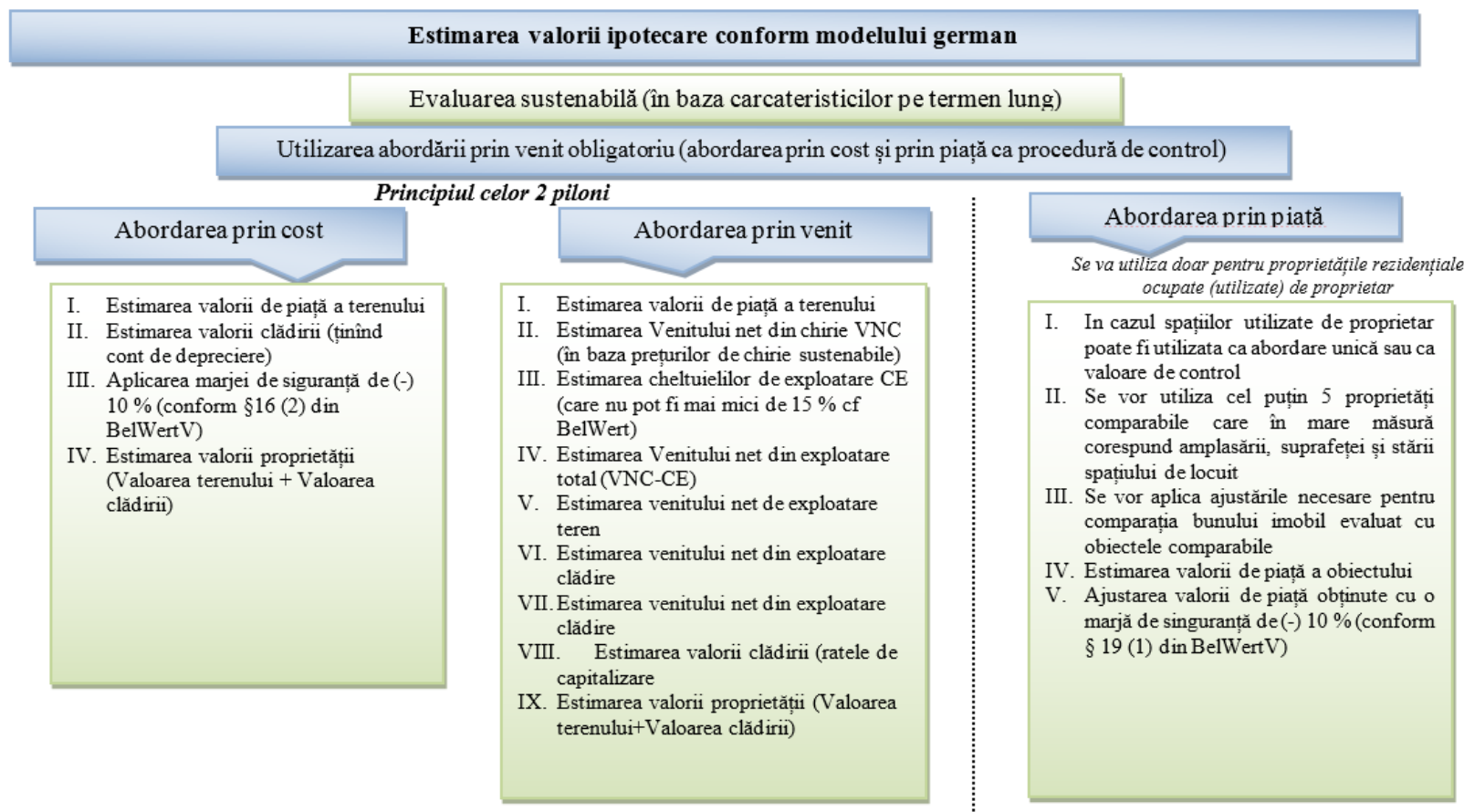

Figura 2. Estimarea valorii ipotecare conform modelului german. Sursa: Întocmit de autor în baza [5, 6, 10, 11, 12].

\subsection{Prevederile de bază ale metodologiei privind valoarea creditului ipotecar}

Venit net din chirii (Venitul Operațional Net): Fluxul de venit generat de proprietate nu ar trebui să fie mai mare decât venitul net sustenabil pe care respectivul tip de proprietate îl generează pe baza unei judecăți a pieței pe termen lung excluzând oricare fluxuri de venit extraordinare sau excepționale. Va fi luat în considerare doar venitul pe care proprietatea îl 
poate genera pe termen lung. Cheltuielile operaționale: Deducerea din venitul net din chirie a tuturor costurilor operaționale și administrative, alocările pentru depreciere, întreținere, reparații curente și capitale, modernizare riscul de neocupare, de neplată a chiriei și alte riscuri posibile care decurg din darea în chirie a proprietății. Regulamentul concretizează că aceste cheltuieli trebuie să fie de minim15 \%.

Rata de capitalizare: Aplicarea ratei de capitalizare trebuie să reflecte tendințele pieței pe termen lung și să excludă așteptările de recuperare a investiției în termen scurt.

Conform regulamentului BelWertW pentru clădirile rezidențiale rata de capitalizare nu poate fi mai mică de $5 \%$, iar pentru proprietățile imobiliare comerciale rata de capitalizare nu poate fi mai mică de $6 \%$. $[6,10,12]$.

Pentru o mai bună înțelegere, a diferenței dintre valoarea ipotecară estimată în baza modelului german și valoarea de piață estimată prin abordarea prin venit, propunem în tabelul 1 un exemplu ipotetic.

Tabelul 1

Diferență între Valoarea ipotecara și Valoarea de piață conform practicii Germane

\begin{tabular}{|c|c|c|}
\hline Valoarea ipotecara & Notă & Valoarea de piață \\
\hline $\begin{array}{r}39000 \text { euro } \\
650 \mathrm{~m}^{2} \times 5 \text { euro } \times 12 \text { luni }\end{array}$ & Venitul brut anual & $\begin{array}{l}46800 \text { euro } \\
650 \mathrm{~m}^{2} \times 6 \text { euro } \times 12 \text { luni }\end{array}$ \\
\hline $\begin{array}{r}5850 \text { euro (15 \% cheltuieli minime conform } \\
\text { BelWert) } \\
\text { Management } \\
15 \%\left\{\begin{array}{r}+ \text { Riscul de neîncasare a chiriei } \\
+ \text { Cheltuieli de întreținere } \\
+ \text { Riscul modernizării }\end{array}\right.\end{array}$ & $\begin{array}{c}\text { Cheltuieli de exploatare } \\
10 \text { spații de birouri - } \\
130 \text { euro/birou -3 \% } \\
4 \text { euro/ m² } \\
\text { În acest exemplu } 0\end{array}$ & $\begin{array}{l}5304 \text { euro } \\
\text { Management } \\
\text { 11,34\% } \\
\text { + Riscul de neîncasare a chiriei } \\
\text { + Cheltuieli de întreținere }\end{array}$ \\
\hline 33150 euro & $\begin{array}{c}\text { Venitul net } \\
\text { din exploatare }\end{array}$ & 41496 euro \\
\hline 19890 (397800 euro x 5\%) & $\begin{array}{l}\text { - Venitul net din } \\
\text { exploatare pentru } \\
\text { teren }\end{array}$ & 17901 (397800 euro x 4,5\%) \\
\hline 13260 & $\begin{array}{l}\text { = Venit net din } \\
\text { exploatare pentru } \\
\text { clădire }\end{array}$ & 23595 \\
\hline $\begin{array}{r}\text { 18,93 (conform anexa } 4 \text { Belwert) } \\
\text { Rata de capitalizare -5\% (minimă } \\
\text { acceptată) } \\
\text { Durata de viața utilă rămasă }-60 \text { ani }\end{array}$ & x multiplicator & $\begin{array}{l}20,64 \\
\text { Rata de capitalizare }-4,5 \% \\
\text { Durata de viața utilă rămasă - } 60 \text { ani }\end{array}$ \\
\hline 251011 euro & = Valoarea clădirii & 487000 euro \\
\hline 397800 euro & $\begin{array}{c}\text { + Valoarea de piață a } \\
\text { terenului }\end{array}$ & 397800 euro \\
\hline 648811 euro & Valoarea proprietății & 884800 euro \\
\hline \multicolumn{3}{|c|}{ Diferența: 37 \% (235 989 euro) } \\
\hline
\end{tabular}

Astfel, pentru un bun imobil cu destinație locativă diferența dintre valoarea de piață și valoarea ipotecară estimată în conformitate cu prevederile practicii germane constituie $37 \%$.

Abordarea prin cost (costul de înlocuire net) și abordarea prin venit sunt principalele metode specificate pentru determinarea valorii creditului ipotecar, pașii de calcul fiind analogici metodelor standarde de determinare a valorii de piață. Valoarea determinată prin cost și valoarea determinată prin venit trebuie estimate separat una de cealaltă. Secțiunea 4, §1 BelWertV evidențiază așa - numitul principiu al celor 2 piloni, exemplificat în Tabelul 2.

Astfel, valoarea determinată cu ajutorul abordării prin cost, servește drept „,valoare de control" pentru valoarea determinată prin venit. Un alt punct reglementat în BelWertV se 
referă la evaluarea proprietăți ocupate de proprietari și proprietăți utilizate în mod autonom, în acest caz valoarea determinată prin abordarea prin comparație poate înlocui valoarea determinată prin costuri. Și aici BelWertV se bazează pe practica îndelungată și permite utilizarea valorilor relevante pe metru pătrat de spațiu de locuit pentru obiecte comparabile (în special apartamente) atunci când se determină valoarea creditelor ipotecare a spațiilor ocupate de proprietari. Prin excepție, pentru simplificare, în cazul estimării valorii caselor de locuit pentru una sau 2 familii ocupate de proprietar, în cazul lipsei îndoielilor, se permite a nu determina mărimea venitului. $[5,6,10,11]$.

Tabelul 2

Principiul celor 2 piloni

Pilonul 1 Abordarea prin Venit
Valoarea terenului
$550 \mathrm{~m}^{2 *} 4150 € / \mathrm{m}^{2}$
Venitul Brut Anual

$1500 \mathrm{~m}^{2 *} 30 € / \mathrm{m}^{2 *} 12$ luni

\section{Cheletuieli de exploatare}

Cheltuieli de management (3\% din Venitul Brut)

Cheltuieli de întreținere (15 €/

$\mathrm{m}^{2}$ )

Riscul de neîncasare a chiriei ( 3

$\%$ din Venitul Brut) Total

Cheltuieli exploatare, \%

Cheltuieli de exploatare minime cf BelWert, (15\% din Venitul

Brut), \%

Cheltuieli de exploatare

obligatorii

(15\% din Venitul Brut), euro

Venitul net din exploatre (VNE),

euro

Rata de capitalizare 6\%

Venitul Net din exploatare

teren, euro

Venitul net din exploatare

clădire

Rata de capitalizare 6\%

Durata de viață utilă rămasă: 60

ani

Multiplicator (cf BelWert)

Valoare clădirii, euro

Valoarea terenului, euro

Valoarea proprietății, euro

\section{Pilonul 2 Abordarea prin Cost}

Valoarea terenului

$550 \mathrm{~m}^{2 *} 4150 € / \mathrm{m}^{2}$

$540000 \quad$ Valoarea clădirii

Costul de construcție

$\left(7600 \mathrm{~m}^{3 *} 530 € / \mathrm{m}^{2}\right)$

4028000

Depreciere (0 \% deoarece este o construcție nouă), 0 Costuri zona exterioara

$16200 \quad$ (3\%), euro

120840

22500

16200

54900

10

Subtotal, euro

3733956

Marja de siguranță (cf BelWert de

$10 \%)$, euro

4148840

414884

Cheltuieli neprevăzute clădire (cf

BelWErt de $16 \%$ ), euro

597433

Valoarea obținută prin abordarea prin cost este cu 11,6 \% mai mică decît valoarea obținută prin abordarea prin venit, ceea ce reprezintă mai puțin de $20 \%$, astfel este respectat principiul celor 2 piloni

Sursa: Întocmit de autor în baza [5, 6, 10, 11, 12].

Binert și Brauner [8] în cercetarea sa au analizat problemele modelului german. Cercetătorii pun la îndoială necesitatea calculului valorii ipotecare (MLV) independent de 
valoarea de piață (MV). Rezultatele studiului indică că cea mai bună modalitate de a obține MLV este din MV estimată. Cu toate acestea, această așa-numita MLV derivată nu poate fi estimată prin deduceri de sumă forfetară din MV.

La nivel național (pentru Germania), noul PfandBG este apreciat pozitiv, spre exemplu pentru că a fost introdusă terminologia comună la nivel internațional. Însă, analiza metodelor de estimare a MLV a înregistrat mai puține progrese în noua reglementare. Autorii consideră straniu acest fapt, deoarece instrumente precum ratingul, simularea sau alte instrumente de gestionare a riscurilor sunt cunoscute în alte domenii ale activității imobiliare. Explică acest lucru prin faptul că în planificarea BelWertV, în cea mai mare parte, experții în evaluarea imobilelor nu au fost implicați. Datorită reglementării excesive și factoriilor de intrare parțial necorespunzători pieței, regulamentul este expus multor critici. Autorii pun la îndoială capacitatea noului sistem de legi de a realiza creditarea garantată și stabilitatea sistemului financiar. Dimpotrivă, datorită reglementării sporite, se creează stimulente pentru a nu analiza generarea riscurilor, ci a se baza doar pe intervalele date. Dacă rezultatele sunt în intervalele BelWertV, evaluarea este practic invulnerabilă.

\section{Practica Federației Ruse în viziunea Fedotova M.A și Minimulin D.V.}

Un alt punct de vedere cu privire la valoarea garanției ipotecare este prezentat de cercetătorii ruși Minimulin D.V. și echipa condusă de Fedotova M.A.

Echipa dnei Fedotova M.A. este de părerea că Valoarea garanției are un caracter probabilistic și depinde atât de perioada de prognoză cât și de diferite scenarii pentru realizarea garanției.

Ca bază pentru determinarea valorii garanției este acceptată Valoarea de piață. Următoarea sarcină este de a anticipa posibilele fluctuații pe durata contractului de împrumut și perioada următoare de colectare a datoriilor, precum și evaluarea impactului condițiilor de vânzare. Reieșind din premisele menționate, modelul funcțional generalizat al valorii ipotecare poate fi prezentat sub forma expresiei: [15].

$$
C V=F\left(M V, t, K_{L}, K_{R}, C, S C H\right)
$$

Unde, CV (colateral value) - valoarea ipotecară; MV(market value) - valoarea de piață a bunului imobil ipotecat; $\mathrm{t}$ - timpul; SCH (schedule) - graficul anticipat de rambursare a creditului; $\mathrm{K}_{\mathrm{L}}$ - coeficientul ce caracterizează modificarea valorii ca urmare a acțiunii factorilor de comercializare a ipotecii în condiții restrânse, ce sunt determinați de către cadrul juridic existent; $K_{R}$ - coeficientul ce caracterizează o eventuală reducere a valorii obiectului legată de condiții atipice de exploatare; C(cost) - mărimea cheltuielilor (exprimată în unități bănești), ce țin atât de procedura de urmărire și comercializare a ipotecii, cât și de caracteristicile nemijlocite ale bunului ipotecat.

Coeficientul ipotecar (un termen nu tocmai corect, dar care deja se utilizează pe larg) este determinat prin corelația:

$$
K=\frac{C V}{M V}
$$

Astfel, coeficientul ipotecar indică cu cât diferă valoarea de piață a bunului la momentul evaluării față de valoarea ipotecară stabilită de bancă pentru tranzacția creditară concretă.

Dependența valorii de piață a obiectului ipotecat de timp este condiționată atât de factori externi (starea pieței, gradul de dezvoltare a tehnologiilor în domeniul dat etc.), cât și 
de factorii interni (condiții de exploatare, caracteristici ale obiectului ipotecat). Numeric această dependență poate fi prezentată sub forma coeficientului de modificare relativă a valorii de piață în timp $\mathrm{K}_{\mathrm{MV}}(\mathrm{t})$.

Valoarea acestui coeficient poate depăși o unitate (de exemplu pentru piața imobiliară, care este în proces de creștere), însă poate fi și sub o unitate (de exemplu pentru mașini și echipament).

La determinarea coeficientului $K_{L}$ apar întrebări legate atât de calculul valorii de lichidare, adică de evidența timpului limitat de expunere, cât și de evidența factorilor ce nu țin de timpul de expunere la vânzarea forțată a bunului, care reduc din valoarea bunului, însăși faptul de sechestru, precum și necesitatea vânzării bunului la licitație.

În cadrul lucrului nemijlocit al subdiviziunilor băncii, activitatea cărora vizează operațiunile cu gajul, determinarea acestui coeficient cel mai frecvent presupune apelarea la experiența empirică a experților în domeniul comercializării diverselor tipuri de bunuri. De regulă, specialiștii experimentați sunt capabili să estimeze adecvat atât perioada necesară de marketing, cât și reducerea respectivă la preț condiționată de vânzarea rapidă a bunului.

Cheltuielile aferente procedurii de urmărire a bunului ipotecat includ mai multe componente eventuale. Astfel, cheltuielile generale cuprind:

a. Taxele de stat în conformitate cu legislația fiscală;

b. Taxă de executare în mărime de $7 \%$ din suma încasată în urma comercializarea bunului;

c. Comisionul RFFI (Fondul bunurilor federale al Federației Ruse) - organizație care desfășoară licitațiile publice (constituie de obicei $5 \%$ din suma încasată în urma comercializării bunului).

Iar cheltuielile specifice cuprind:

d. cheltuielile de publicitate, evaluare, servicii de consultanță;

e. cheltuielile de întreținere a bunului în perioada desfășurării procesului executoriu și a comercializării (paza, arenda încăperilor, achitarea serviciilor comunale etc.);

f. cheltuielile de transport

g. cheltuieli neprevăzute.

Pentru diferite tipuri de bunuri structura și mărimea cheltuielilor poate fi diferită.

Modelul funcțional al valorii ipotecare în cazul comercializării obiectului ipotecat la licitație publică este propus în forma următoare:

$$
C V(t)=M V \times K_{M V\left(t+t_{p}\right)} x K_{L} x K_{R}-\frac{C}{M V}
$$

Unde, $t_{p}$ - timpul necesar pentru desfășurarea etapelor procedurilor judiciare, a procesului executoriu, precum și a comercializării bunului (e caracteristică o perioadă de 6-18 luni); C-mărimea cheltuielilor; $K_{M V}(t)$ - coeficientul ce caracterizează modificarea în timp a valorii de piață a bunului.

Respectiv formula coeficientului ipotecar va arăta în felul următor:

$$
K(t)=1-K_{M V\left(t+t_{p}\right)} x K_{L} \times K_{R}+M V
$$

Modelul dat poate fi aplicat și în cazul comercializării benevole a bunului ipotecat de către debitor, desfășurat sub controlul băncii. În acest caz se reduc semnificativ atât intervalul de timp, cât și cheltuielile aferente.

Un împrumut poate fi considerat ca asigurat (cu riscuri minime) de facto, în cazul în care mărimea obligațiunilor aferente acestui împrumut nu depășește valoarea ipotecară. 
După cum ne demonstrează modelul examinat mai sus, valorile unui șir de componente ce influențează mărimea valorii ipotecare și respectiv cea a coeficientului ipotecar, se calculează cu un anumit grad de convenționalitate, din acest motiv și determinarea mărimii coeficientul ipotecar implică un grad anumit de relativitate. Totuși acest lucru nu știrbește din valoarea practică a modelului, din moment ce în cadrul practicii bancare existente discreditarea coeficienților ipotecari de regulă nu este mai joasă de 10\%.

O altă tehnică de determinare a coeficientului ipotecar, care este aplicată mai frecvent în cadrul practicii bancare ruse a fost generalizată de către dul Minimulin D.V. Tehnica este bazată pe principiul de calcul al valorii ipotecare a garanției în baza evaluării de piață $[1,16]$.

$$
H V=M V x(1-D)
$$

Unde, HV - valoarea ipotecară, MV-valoarea de piață, D - rata coeficientului ipotecar.

Astfel, are loc transformarea valorii de piață în valoare ipotecară prin prisma mărimii coeficientului, valoarea căreia este determinată în mod individual în conformitate cu regulamentele și prevederile intra bancare aprobate. În cadrul acestui proces parametrii coeficientului ipotecar pentru bunurile ipotecate urmează a fi determinate ținând cont de conjunctura curentă a pieței și de tendința predictibilă de dezvoltare.

Tehnica general acceptată de calcul intra bancar al valorii ipotecare prin aplicarea coeficientului ipotecar în baza mărimii de evaluare a valorii de piață rezidă în stabilirea valorii parametrului coeficientului ipotecar (al intervalului de valori admisibile) pentru fiecare tip de active gajate (grup de active gajate). Determinarea mărimii coeficientului ipotecar pentru obiectele de gaj se efectuează în cadrul regulamentelor și prevederilor intra bancare aprobate, fapt ce presupune corespunderea necondiționată a parametrilor indicați strategiei și tacticii optate de dezvoltare a organizației creditare.

În cadrul practicii bancare ruse [16] mărimea coeficientului ipotecar este determinată prin intermediul a doi parametri:

- primul parametru reprezintă estimarea costului cheltuielilor anticipate pentru comercializarea obiectului garantat;

- cel de-al doilea parametru este marja de siguranță sau componenta extraordinară.

Altfel spus, aceasta este suma reducerii valorii în legătură cu necesitatea de comercializare forțată și rapidă a obiectelor de gaj.

$$
D=\frac{C}{M V} 100 \%+M_{S}
$$

Unde, D - rata coeficientului ipotecar; C - cheltuielile anticipate de comercializare a gajului; MV - valoarea de piață a obiectului ipotecat; Ms - marja de siguranță.

Astfel, prin aplicarea coeficientului ipotecar la valoarea de piață a bunului se realizează transformarea ultimei în valoare ipotecară, care ia în calcul cheltuielile anticipate pentru comercializarea bunurilor, precum și cheltuielile legate de necesitatea de comercializare forțată și rapidă a obiectelor ipotecate.

În cadrul procesului de formare a valorii ipotecare coeficientul ipotecar se manifestă în calitate de sistem de filtre, care sunt agregate pentru realizarea unei sarcini comune și diferențiate conform destinației lor funcționale. Fiecare parametru inclus în valoarea coeficientului ipotecar lansează un mecanism propriu de protecție în caz de materializare a tipului de risc corespunzător lui.

În cadrul estimării valorii ipotecare coeficientul ipotecar joacă un rol de airbag (dispozitiv de siguranță), din motiv că funcția de asigurare a gajului este realizată anume prin 
intermediul valorii coeficientului ipotecar, și anume a componentei sale - marja de siguranță. Să facem o detaliere a noțiunii de marjă de siguranță, adică a gradului de reducere a valorii gajului în caz de comercializare forțată a lui. Practica bancară rusă de creditare, asigurată prin grevare de bunuri și drepturi de proprietate a condus la elaborarea unei abordări individuale față de determinarea marjei de siguranță bazate pe opinia experților. Pentru fiecare tip de garanție a fost stabilită mărimea proprie a marjei de siguranță.

Prin agregarea argumentelor aduse mai sus, calculul mărimii coeficientului ipotecar în cadrul realizării practice a gestiunii se poate efectua în modul următor:

$$
D=\left(\frac{C}{M V}+\frac{L}{M V}\right) 100 \%=I_{C}+M_{S}
$$

unde: D- rata coeficientului ipotecar ; C- cheltuielile anticipate de comercializare; MVvaloarea de piață a ipotecii; L - mărimea pierderilor din valoare; Ic - cota cheltuielilor anticipate de comercializare în valoarea de piață a bunului; Ms- marja de siguranță.

Totuși estimarea gradului de reducere a valorii bunului ipotecat în situația de materializare a riscului de credit pe împrumutul acordat se efectuează de către comunitatea bancară cu admiterea unui șir de prevederi:

o lipsa unei crize sistemice a sistemului financiar;

o prezența pieței de desfacere pentru activele ipotecate;

o situația financiară a băncii creditoare se estimează ca fiind una bună.

Din moment ce parametrii de calcul ai formulei 7 reprezintă în sine niște mărimi prognozate în baza estimărilor experților, calculul coeficientului ipotecar se efectuează întotdeauna cu o anumită marjă de eroare și este evaluat prin intermediul modelului de regresie:

$$
D_{i}=\beta_{0}+\beta_{1} x I_{C}+\beta_{2} x M_{S}
$$

unde: Di - coeficientul ipotecar pentru ipoteca "i"; Ic - ponderea cheltuielilor anticipate de comercializare a ipotecii "i" în valoarea de piață; Ms - marja de siguranță stabilită pentru ipoteca "i".

Metodele descrise mai sus iau în calcul o mulțime de parametri, determinarea cărora ține de experiența practică acumulată de bănci și de statistica pe tipuri de garanții, pe modificările în timp a valorii, pe influența diverșilor factori asupra acestei valori etc. Nu există abordări universale în cadrul acestui subiect. Mai mult ca atât, în cadrul organizațiilor de credit se admite aplicarea coeficienților ipotecari proprii. În Tabelul 3 sunt prezentate dezavantajele acestor modele.

Tabelul 3

\section{Dezavantajele de bază a modelelor de calcul a coeficientului ipotecar}

Modelul valorii ipotecare prezentat de Minimulin D.V. [47]

Riscurile incluse în categoria "marjă de siguranță" reprezintă niște indicatori prea generalizați, care nu sunt evidențiați separat, fapt ce la rândul său nu permite analiza factorilor care acționează asupra acestui indicator. Modelul valorii ipotecare prezentat de Fedotova M.A. [25]

Modelul dat examinează într-o măsură mai mare modificarea valorii bunului gajat ca urmare a acțiunii condițiilor de comercializare a gajului din afara pieței, care sunt determinate de cadrul juridic existent privind cheltuielile de urmărire și comercializare a bunurilor ipotecate. 
Continuare Tabelul 3

Această mărime se calculează pe calea expertizei în baza opiniei evaluatorului sau a specialistului intern, care la rândul său poate fi una subiectivă.
El însă nu ia în considerație eventualele riscuri legate de tipul bunului imobil, de segmentul de piață și starea lui. Coeficientul obținut în urma aplicării acestui model poate fi definit mai degrabă ca coeficient de lichidare, și nu ca coeficient ipotecar.

Sursa: elaborate de autor în baza [1, 15, 16].

În baza modelelor examinate putem concluziona, că nici unul din modele nu ne prezintă o viziune clară a tehnicii de calcul a coeficientului ipotecar. În ambele modele figurează noțiuni generale, fapt ce le face destul de dificile pentru aplicarea în practică.

\section{Estimarea valorii ipotecare conform Alianței Proprietăților Industriale din Marea Britanie}

O analiză asupra alternativelor metodologice de estimare a valorii ipotecare (valoare pe termen lung) a fost efectuată de către Alianța Proprietăților Industriale din Marea Britanie în anul 2017 (Property Industry Alliance) în continuare API, din care fac parte: Association of Real Setate Fund (AREF); British Council for Office (BCO); British Prosperat Federațiune (BPF); Comercial Real Setate Finanțe Council Europe (CREFC Europe); Investment Prosperat Forum (IPF); Revoc; Royal Institution of Chartere Surveyors (RICS); Urban Land Institute (ULI) [17].

API consideră că împrumuturile garantate cu bunuri imobile ar trebui să constituie o activitate destul de simplistă deoarece valorile lor pot fi estimate și riscurile identificate. Concluzia principală a studiului efectuat de API este că Valorile pe termen lung pot furniza semnale atunci când piața imobiliară poate fi supraestimată sau pot prevedea riscul modificării valorii bunurilor imobile în timp. Acest studiu a fost efectuat pentru Instituțiile de creditare pentru ai încuraja să ia în considerare faptul că doar Valoarea pe termen lung poate avea un rol central în sistemul de gestionare a riscului de credit.

Grupul de lucru API a luat în considerare 3 abordări alternative care ajută la determinarea Valorii pe termen lung

$\checkmark$ Valoarea de piață ajustată (AMV)

$\checkmark$ Valoarea investițională (IV)

$\checkmark$ Valoarea ipotecară(MLV)

\subsection{Valoarea de Piață Ajustată (AMV- de la Adjusted Market Value)}

AMV reprezintă o abordare empirică care pornește de la supoziția că valoarea imobilelor (în special comerciale) urmează o tendință pe termen lung. Se presupune că devierea de la această tendință nu cauzează corecții ulterioare ale pieței, însă poate fi observat faptul că o asemenea deviere are o corelație strânsă cu ajustările ulterioare ale pieței. În cadrul abordării AMV, valoarea de piață a bunului este ajustată în direcția descreșterii (sau a creșterii) sale pentru a reflecta gradul în care piața imobilelor comerciale se situează deasupra (sau sub) nivelul tendinței de lungă durată a pieței - cea ce și reprezintă în sine "ajustarea pieței". Linia tendinței de piață se bazează pe istoricul setului de date statistice ajustate cu mărimea inflației. Se pornește de la premisa că, fiind ajustată la inflație, analiza tendințelor din trecut a fluctuației valorilor pe parcursul unui ciclu, poate fi utilizată pentru identificarea și anticiparea tendințelor viitoare.

Deși AMV este mai mult analizată și articulată la nivelul macro al pieței decât la nivelul bunului individual, ea poate fi la fel de ușor operată și la nivelul bunului individual în tandem cu valoarea de piață a proprietății individuale. 


\section{Calculul AMV}

$\begin{array}{cc}\text { Formula de bază } & \text { Varianta simplificată } \\ A M V=M V \times \frac{A e^{(-b t)}}{\frac{C V I_{t}}{R P I_{t}}} & A M V=M V \times(1-M A)\end{array}$

Unde:

$M V$ = valoarea de piață (market value);

$A$ și $b$ = parametrii pentru cea mai bună potrivire exponențială

$\mathrm{CVI}_{(t)}=$ Indicele costului capitalului (în momentul de timp $\mathrm{t})$;

$\mathrm{RPI}_{(\mathrm{t})}=$ indicele inflației (în momentul de timp t).
Unde:

MA- este factorul de ajustare a pieței, care reflectă diferența dintre valoarea de piață și tendința de lungă durată a valorii ajustate la inflație, calculate trimestrial.

\section{Sursa: [17].}

Necesitatea determinării unei mărimi eficiente a valorii de piață ajustate AMV implică aplicarea unui indice al prețului de piață sau a unui set de date pe termen lung. În Marea Britanie acestea există pentru un anumit șir de segmente de piață și poate fi desfășurată o analiză de regresie pentru un șir de cicluri majore. Disponibilitatea acestor date face posibilă ca AMV să fie testată în cel mai ușor mod, anume prin prisma capacității sale de a prognoza supra- și sub-evaluarea pieței, având o perioadă de acoperire a ciclurilor de piață de aproape un secol și conținând date trimestriale care permit efectuarea avertizărilor timpurii.

\subsection{Valoarea de Investiție (IV)}

Valoarea de Investiție (IV) este definită în Standardele Internaționale de Evaluare (IVS) și este cel mai frecvent interpretată ca prețul pe care investitorul trebuie să-l plătească pentru o investiție, fiind distinct de prețul pe care investitorul trebuie să-l plătească pieței (prețul de piață). În definiția curentă IVS, Valoarea de investiție este identificată prin referirea la circumstanțele investitorului individual, care ar putea achiziționa bunul ("valoarea aferentă individului").

Definițiile anterioare IVS, includeau conceptul de "valoare aferentă pieței".

Noțiunea de IV este abordată de obicei la nivelul proprietății individuale, deși în studiul API, principiile au fost aplicate față de piață ca un tot întreg și (în măsura posibilităților) față de sectoarele și sub sectoarele proprietăților investiționale. Valoarea investiției reprezintă o funcție al fluxului de numerar net, pe care îl va genera bunul și a rentabilității sale solicitate de către investitori. Abordarea comună în cadrul piețelor de bunuri constă în aplicarea modelului standard al fluxului de numerar actualizat (DCF - discounted cash flow) cu utilizarea mărimii curente și a mărimilor anticipate pe viitor ale valorilor de locațiune, de transmitere în chirie și a profitului sumar de investire la sfârșitul unei perioade presupuse de deținere. Fluxul net de numerar este actualizat pe parcursul acestei perioade la o rată de rentabilitate.

$$
I V=R \frac{1-(1+r)^{-n}}{r}+\frac{R(+g)^{\Delta n}}{k(1+r)^{\Delta n}}
$$

Unde: $\mathrm{R}$ = valoarea chiriei în anul $0, \mathrm{n}=$ perioada chiriei, $\mathrm{r}$ - rata de actualizare, $\mathrm{k}=$ rata de vânzare a bunului la sfârșitul perioadei de chirie, $g$ = prognoza anuală a modificării prețurilor de chirie. 


\subsection{Valoare ipotecară (MLV)}

MLV reprezintă o valoare sustenabilă. În cadrul cercetării, abordarea germană a servit ca model primar pentru determinarea valorii ipotecare. Scopul valorii ipotecare este de a stabili o valoare pe care activul este susceptibil să o mențină, cu un grad înalt de certitudine, pe parcursul perioadei luate în considerare (de obicei perioada de împrumut), pentru a asigura un nivel înalt de încredere că împrumutul poate fi rambursat din valoarea activului. Valoarea ipotecară (MLV) se aplică în mod normal la nivelul proprietății individuale. Cu toate acestea, adoptarea unor valori de bază similare pentru valoarea de piață și valoarea investițională, înseamnă că MLV poate fi comparată cu acestea și poate fi utilizată și pe alte piețe cu careva modificări și adaptări (în cadrul studiului făcând-se referință la piața Marei Britanii).

În mod normal MLV este aplicată la nivelul bunului individual. Totuși prin adoptarea intrărilor similare ale valorii de bază în cazul valorii de piață și IV înseamnă că MLV poate fi comparată cu ele și poate, de asemenea, fi evaluată la nivelul pieței agregate sau la nivel de portofoliu. În urma studiului s-a constatat că pentru a adapta prescrierile versiunii germane de determinare MLV în cadrul Regatului Unit, unele din intrări necesită modificări, după cum se relatează mai jos.

- Chirie sustenabilă: Abordarea germană permite utilizarea valorii de închiriere curente de piață în calitate de mandat pentru o chirie sustenabilă. Acest lucru nu este pe deplin satisfăcător pentru Regatul Unit. În Germania majoritatea piețelor bunurilor imobiliare au fost în mod tradițional mai puțin volatile decât piețele din Regatul Unit. Adoptarea unei asemenea metodologii în cadrul Regatului Unit necesită muncă detaliată suplimentară (care este recomandată mai jos ca o etapă următoare) pentru identificarea unei abordări alternative, mai potrivite de definire a valorilor de închiriere sustenabile. Între timp cel de-al doilea element "nepotrivit" pentru piața Regatului Unit (vezi punctul mai jos) a fost folosit pentru aI face să funcționeze corect.

- Cheltuieli operaționale: metodologia Pfandbrief prescrie o deducere de minim $15 \%$ din Venitul net din chirie. În contextul realităților Regatului Unit acest nivel minim cu greu poate fi justificat deoarece în cadrul multor tranzacții de închiriere din Regatul Unit are loc transferul obligațiilor de reparare sau de asigurare a bunului către chiriași. Totuși, acest element a fost păstrat în pofida tendinței sale de a subestima valoarea de închiriere în cadrul Regatului Unit, din motiv că el parțial compensează supraestimarea valorii ce apare în legătură cu utilizarea prețurilor curente de închiriere (după cum a fost evidențiat în itemul de mai sus).

- Valoarea terenului: în Germania valoarea terenului a rămas relativ stabilă și datele respective sunt disponibile în baza de date, fapt ce face separarea valorii pământului de cea a edificiului un lucru simplu. Aceasta însă nu este și cazul Regatului Unit, unde valoarea loturilor de pământ este mult mai volatilă și nu există o bază de date a valorii lor curente de piață. În baza datelor studiului desfășurat de Crosby, Devaney și Wyatt în cadrul acestei analize s-au făcut următoarele ipoteze privind proporția pământului și clădirii: 50:50 pentru obiectele de tip retail, 30:70 pentru oficii și 10:90 pentru cele industriale.

- Deprecierea clădirilor: actul Pfandbrief stabilește o perioadă maximă de decontare de 60 ani pentru Oficii și pentru Obiectele Retail (clasificate ca "Imobile Comerciale"). În scopul acestui studiu este utilizat termenul de 50 ani pentru Oficii, 30 ani pentru Obiecte Industriale și 70 ani pentru Obiectele Retail. O perioadă atât de lungă pentru Obiectele Retail este justificată prin predominarea Obiectelor Retail din blocuri etajate. La nivelul tuturor bunurilor imobiliare analiza utilizează termenul de 50 ani. De asemenea e necesar de 
menționat că analiza a fost desfășurată fără a lua în calcul loturile de pământ pe care sunt amplasate imobilele: s-a făcut separarea edificiilor de pământ. Trezește interes faptul că în rezultat nu a fost remarcată o diferență semnificativă în ce privește nivelul sau forma MLV pe parcursul perioadei de timp.

- Rentabilitatea: Ratele de capitalizare preconizate de Actul Pfandbrief sunt în intervalul $6 \%$ - 7,5\% pentru Oficii și obiecte comerciale și pentru Obiectele industriale - în intervalul $7 \%$ - 9\%. Activele primare (care totuși nu sunt definite pe larg) pot beneficia de un discount de până la 0,5\% sub nivelul minim aplicat. Modelul MLV din cadrul studiului realizat de API utilizează cea mai înaltă din ratele de capitalizare actuale de 7,5\% pentru Oficii și pentru Obiectele Retail și de $9 \%$ pentru Obiectele Industriale. Pentru toate bunurile imobiliare model analizat utilizează rata de $7,5 \%$.

- Durata și ponderea: Pământul este capitalizat pe durată nedefinită, iar edificiile sunt capitalizate pentru durata de viață rămasă. Valorile sunt apoi ponderate prin raportul teren: construcție (conform ponderii indicate mai sus) și însumate pentru a ajunge la MLV. În scopul acestui studiu valoarea MLV a fost adaptată și aplicată pentru toate categoriile de imobile, sectoarele și sub sectoarele. În rezultat această abordare față de MLV german ignoră „cel deal doilea pilon" al abordării germane MLV, care este bazat pe cost și care este destul de specific.

Concluzia de bază a studiului este că estimarea valorii pe termen lung poate furniza semnale utile, atunci când piața imobiliară riscă de a fi supraevaluată și să fie expusă riscului ridicat de scădere semnificativă a valorii.

Dintre toate metodele analizate MLV (Valoarea ipotecară) este cea mai fiabilă cu toate că sunt necesare unele adaptări și îmbunătățiri tehnice pentru a putea fi utilizată pe piața Marei Britanii sau pe alte piețe.

Instituțiile de creditare sunt încurajate să ia în considerare modul în care activitatea de garantare a împrumuturilor, estimarea valorii pe termen lung poate avea un rol central în sistemul de gestiune a riscului. În prezent sunt efectuate studii suplimentare pentru a finaliza analiza diferitelor abordări și a analiza modul în care acestea ar putea fi utilizate cel mai bine de către instituțiile creditoare și de autoritățile de reglementare [17].

\section{Modelul spaniol de determinare a valorii ipotecare}

Un alt model practicat care consideră Valoarea ipotecară este Modelul Spaniol. Ordinul Ministerului Economiei, ECO/805/2003 [18] din 27 martie, privind standardele de evaluare a bunurilor imobile și anumite drepturi în scopuri financiare, stabilește principiile detaliate de evaluare. Acest ordin vine ca un amendament la o ordonanță anterioara din 1994, iar unul din motivele majore pentru noul ordin era să ia în considerare valoarea pe termen lung a proprietăților.

Ordinul definește Valoarea ipotecară (VH) sau valoarea creditului ipotecar ca fiind „valoarea proprietății determinată printr-o evaluare prudentă a posibilității viitoare de tranzacționare a proprietății, luând în considerare aspectele durabile pe termen lung ale acesteia, condițiile normale și locale ale pieței, utilizarea acesteia în momentul evaluării precum și cea mai bună și eficientă utilizare. Evaluarea nu va conține elemente speculative.

Această definiție este apropiată cu definițiile din Legislația Europeană. Articolul 2 si 45 sunt deosebit de relevante, deoarece definesc domeniul de aplicare a ordinului și detaliile privind modul în care trebuie aplicate modelele de valoare pentru evaluarea obiectelor ipotecate și ale fondurilor de pensii. Ordinul nu efectuează o distincție esențială între 
Valoarea de piață și Valoarea ipotecară, prin urmare abordarea valorii ipotecare este mai puțin prescriptivă față de abordarea germană de determinare a valorii ipotecare.

Regulile de bază pentru estimarea valorii ipotecare în modelul spaniol cuprind:

\section{a. Pentru clădirile aflate în proces de construcție sau reabilitare:}

o Valoarea estimată va fi valoarea de înlocuire netă. În cazul în care lucrările de construcție au fost paralizate și nu se prevede reluarea lor în termen scurt, valoarea considerată va fi cea mai mică dintre valoarea de înlocuire și valoarea reziduală a terenului și a clădirii.

o În cazul clădirilor la faza de proiect, în construcție sau reabilitare estimarea valorii se va face pe baza ipotezei lucrărilor finalizate la data planificată.

\section{b. Pentru clădirile finalizate}

o Pentru bunurile imobile exploatate în cadrul unei activități economice, valoarea se va estima în primul rând prin abordarea prin comparație ajustată și, daca este posibil, se va estima valoarea de înlocuire netă și valoarea prin abordarea prin venit (tehnica de actualizare). Valoarea cea mai mică rezultată va fi considerată drept valoarea ipotecară.

- Pentru bunurile imobile închiriate cu excepția spațiilor de locuit, se va estima valoarea cu ajutorul metodei de actualizare și abordării prin comparație (daca este necesar ajustate), în baza presupunerii că este liberă de chiriaș și cea mai mică dintre ele va fi acceptată în scop de garantare a creditului ipotecar.

o Pentru bunurile imobile locative care sunt închiriate la data evaluării, valoarea va fi calculată cu ajutorul abordării prin comparație și tehnicii de actualizare ținând-se cont de fluxurile de venit generate de proprietate la data evaluării conform contractelor de închiriere existente în vigoare, luând în considerare clauzele contractuale ale acestora, iar perioada de calcul va fi perioada contractului rămasă în vigoare. În cazul în care fluxurile de numerar ale bunurilor supuse evaluării sunt superioare altor proprietății comparabile, vor fi înlocuite cu prețurile de piață ale proprietăților comparabile, cu condiția că diferența poate fi atribuită elementelor speculative.

o În cazul altor tipuri de proprietăți, ca de exemplu clădiri destinate pentru uz propriu, clădiri libere, care nu au o destinație concretă, valoarea se va estima prin abordarea prin comparație ajustată. Atunci când nu este posibil se aplica abordarea prin venit tehnica de actualizare (în cazul în care există piață de închiriere pentru obiectul evaluat conform art. 28.)

o Fluxurile de venit se vor estima pentru întreaga durată de viață utilă, luând în considerație toți factorii care ar putea afecta valoarea. Vor fi luate în considerare doar circumstanțe sau situațiile care probabil se vor menține pe termen mediu și lung. Calculul cheltuielilor va include orice tip de cheltuială curentă sau previzibilă, care trebuie suportată de proprietar, fie direct atribuite proprietății (întreținere, administrare, impozite, taxe, etc.) În cazul în care nu este posibilă nici estimarea acestei valori, valoarea va fi cel mult valoarea de înlocuire netă a proprietății.

Cu privire la metodologia propriu zisă, în conformitate cu cele menționate mai sus, pentru estimarea valorii ipotecare se vor aplica cele 3 abordări în conformitate cu prevederile art.45. Abordarea prin comparație va fi aplicată pentru toate tipurile de proprietăți ori de câte ori va fi posibil.

\section{Principiile de bază în cadrul Abordării prin comparație:}

Se va utiliza pentru evaluarea tuturor tipurilor de bunuri imobile cu condiția: 
$\checkmark$ existenței unei piețe reprezentative pentru proprietățile comparabile;

$\checkmark$ existenței datelor suficiente privind tranzacțiile sau ofertele obiectelor comparabile (cel puțin 6 comparabile);

$\checkmark$ disponibilitatea datelor adecvate (tranzacții, oferte) pentru a estima evoluția prețurilor obiectelor comparabile cu cel puțin 2 ani înaintea evaluării;

$\checkmark$ furnizării informații corespunzătoare (date proprii, publicații sau alte date cu privire la indicii de evoluție a prețurilor);

* Se va estima valoarea propriu zisă prin ajustarea comparabilelor. Valoarea estimată va ține cont de cheltuielile necesare pentru vânzarea proprietății.

* În cazul clădirilor la faza de proiectare, construcție sau reconstrucție valoarea se va determina pe ipoteza clădirii viitoare finisate. Se vor utiliza prețurile de piață existente la data evaluării pentru obiectele finalizate. Aceasta valoare poate fi corectată în funcție de tendința pieței pentru perioada de finalizare a lucrărilor.

Valoarea obținută prin abordarea prin piață va fi ajustată (cu un coeficient de ajustare) de către entitatea de evaluare, pentru a obține valoarea de ipotecă (MLV) bazată pe supoziția că valoarea estimată va înregistra o reducere semnificativă nominală, în termen de un an de la data evaluării, reducere care durează cel puțin 3 ani.

o coeficientul de ajustare se bazează pe capacitatea tehnică a evaluatorului de analiză a pieței;

o atunci când nu sunt disponibile date cu privire la comportamentul pieței evaluatorul aplică o reducere de $10-15 \%$.

\section{Principiile de bază în cadrul Abordării prin venit:}

Abordarea prin venit, metoda fluxului de numerar actualizat, se va aplica în conformitate cu prevederile art.45 și va fi aplicat tuturor tipurilor de proprietăți capabile să producă chirii.

* Pentru utilizarea metodei de actualizare este necesar să fie îndeplinite cel puțin una din următoarele condiții:

o existența pe piața chiriilor a obiectelor comparabile (cel puțin 6 obiecte comparabile), pentru a reflecta în mod adecvat situația actuală a pieței;

o existența unui contract de închiriere a bunului supus evaluării, sau obiectul evaluat aduce sau poate aduce venit din activitatea economică, sau există suficiente date contabile sau informații adecvate privind ratele medii în ramură din activitatea corespunzătoare;

o să se dispună de date adecvate (tranzacții oferte) pentru a estima evoluția prețurilor chiriei obiectelor comparabile cu cel puțin 2 ani înaintea evaluării;

o să se dispună de informații adecvate (date proprii, publicații sau alte date cu privire la indicii de evoluție a prețurilor), asupra comportamentului istoric al prețurilor proprietăților similare.

* Procedura de calcul a valorii prin metoda fluxului de numerar actualizat (conform art. 26) este analogică cu cea prevăzută în IVS, obligatoriu se va ține cont și de Valoarea cheltuielilor actualizate legate de proprietate în momentul evaluării.

\section{Principiile de bază în cadrul Abordării prin cost:}

* Abordarea prin cost, va fi aplicabilă în evaluarea tuturor tipurilor de clădiri și elemente ale clădirilor aflate în faza de proiect, în construcții sau reconstrucții, finalizate.

* Cu ajutorul abordării prin cost se va determina valoarea de înlocuire (brută sau netă).

* Procedeul de calcul presupune că la valoarea terenului (determinată prin metoda comparației fie metoda reziduală) se vor adăuga costul lucrărilor de construcție sau de 
reabilitare (care vor include totalitatea cheltuielilor generale de execuție, materiale, cheltuielile de regie și beneficiul constructorului) precum și cheltuielile necesare pentru înlocuire (taxe, pentru proiect, licențe, taxe de construcție, asigurare, inspecție tehnică, cheltuieli de administrare, marketing etc).

* In cazul obiectelor aflate în faza de proiect sau în construcție/reconstrucție, valoarea se va determina pe ipoteza construcției finalizate la data evaluării cu corectarea prețului în dependență de evoluția prețurilor până la data finalizării lucrărilor.

* Pentru estimarea valorii de înlocuire nete se va deduce din valoarea brută mărimea deprecierii (fizice și funcționale) acumulate.

* Deprecierea fizică va fi calculată în baza duratei de viață utilă totală și reziduală estimată de evaluator. În cazul conferirii diferitelor durate de viață utilă elementelor constructive ale clădirii, se va efectua o justificare adecvată. Mărimea deprecierii se va determina prin tehnica de amortizare liniară prin împărțirea vârstei proprietății la durata de viață utilă totală estimată de evaluator dar care nu poate depăși:

o Pentru clădirile locative - 100 de ani

o Pentru clădirile de birouri - 75 de ani

o Pentru clădirile comerciale - 50 de ani

o Pentru clădirile industriale - 35 de ani.

* Deprecierea funcțională se va determina prin estimarea tuturor costurilor și cheltuielilor necesare transformării clădirii actuale într-o clădire nouă cu caracteristici similare.

\section{Concluzii}

Autoritățile de supraveghere bancară atenționează asupra faptului că valoarea care va asigura un credit ipotecar trebuie să fie un instrument de gestionare a riscurilor unde sunt luate în considerare doar aspectele pe termen lung și lipsesc speculațiile.

Pe lângă Valoarea de piață, Autoritățile prin Regulamentele și Directivele elaborate acordă o atenție deosebită Valorii ipotecare (MLV și SLTV), care se consideră ca ar trebui să joace un rol central în practica evaluărilor în scop de garantare a împrumuturilor. Astfel, se consideră că, de fapt Valoarea ipotecară (MLV și SLTV) este un instrument de management al riscului care oferă o anumită protecție în timp.

În contextul celor enunțate, reglementările UE, ar trebui să stabilească anumite principii generale care ar servi drept bază întru estimarea valorii prudente a proprietății imobiliare, sprijinite de ghiduri și standarde de evaluare, dar cel mai important aplicabile în mod egal pe toate piețele imobiliare naționale. Implementarea acestui concept, va produce modificări în cadrul profesiei de evaluator și a practicilor bancare, astfel sunt necesare studii amănunțite, care ar facilita implementarea definiției din Regulamentul Basel III, care ar contribui la o implementare fără probleme a acesteia.

Totodată vom atenționa asupra faptului că piețele emergente diferă considerabil de cele dezvoltate, respectiv nu toate recomandările viabile pentru unele sunt aplicabile pentru altele. Respectivele aspecte urmează a fi cercetate și structurate într-o metodologie practică aplicabilă și pentru condițiile Republicii Moldova.

\section{Referințe bibliografice}

1. Minimulin D. V. Collateral risk in the structure of bank credit risk and its assessment. In: Money and Credit, 2009, No. 4 [in Russian].

2. Regulamentul nr. 575/2013 al Parlamentului European și al Consiliului din 26 iunie 2013 privind cerințele prudențiale pentru instituțiile de credit și societățile de investiții și de modificare a Regulamentului (UE) nr. 648/2012. Disponibil: https://eur-lex.europa.eu/legal-content/ro/TXT/?uri=celex:32013R0575 
3. Basel Committee on Banking Supervision, Basel III: Finalising post-crisis reforms, December 2017, Disponibil: https://www.bis.org/bcbs/publ/d424.pdf

4. RICS professional standards and guidance, Europe Bank lending valuations and mortgage lending value. Disponibil:https://www.rics.org/globalassets/rics-website/media/upholding-professional-standards/sectorstandards/valuation/bank-lending-valuations-and-mortgage-lending-value-1st-edition-rics.pdf

5. Pfandbrief Act (Pfandbriefgesetz), Parlamentul german (2005), Act din 22 noiembrie 2005 publicat în The German Official Journal, partea I, nr 29: 1373 Disponibil: European Covered Bond Council http://www.ecbc.eu/legislations/90/Pfandbrief+Act+\%28as+of+November+2015\%29.pdf

6. Property Industry Alliance (PIA) Long-term Value Working Group, Commercial Real Estate Finance Council Europe (CREFC Europe) and Investment Property Forum (IPF), 30 June 2017.

7. Parlamentul german. Regulation on the Determination of the Mortgage Lending Value - BelWertV) din 12 mai 2006, publicat în The German Official Journal,2006, Partea I, nr. 24.

8. Bienert S., Brunauer W. The mortgage lending value: prospects for development within Europe. In: Journal of Property Investment\& Finance, Vol. 25 No. 6, pp. $542-578$.

9. Kierig J. Zum neuen Pfandbriefgesetz und dem Entwurf der Beleihungswertermittlungsverordnung (BelWertV), In: Vortrag auf dem 14,Wertermittlungsforum, Jahreskongress.

10. Kleiber W. Babylon schreitet voran. In: Grundstucksmarkt Und Grundstuckswert, Koln, Vol. 6, p. 1.

11. Quentin J. The Subprime Crisis - Implications for Property Valuation? The revival of Mortgage Lending Value. In: The Appraisal Journal, vol. 77, no. 4, pp. 312 - 318.

12. The Regulation on the Determination of the Mortgage Lending Value - Greater Safety in Valuation for Mortgage Purposes. Achim Reif. Association of German Pfandbrief Banks. Disponibil: https://www.pfandbrief.de/site/dam/jcr:301f9658-936a-401e-8ec1804e2aa5fc69/FBI_2006_Reif_Mortgage_Lending_Value.pdf 2.

13. Basic principles of the Mortgage Lending Value methodology. Disponibil: http://collateralrisknetwork.com/wp-content/uploads/2015/04/wolfgang_and_lux_presentation.pdf

14. Down K. Measuring Market Risk. John Wiley of Sons, Chichester, 2002.

15. Fedotov M. A., Roslov V.Yu., Sherbakova O. N., Myshanov A.I. M. Valuation for the purposes of collateral: theory, practice, recommendations. Finance and Statistics, 2008.

16. Minimulin D.V., Radaev N. N. Formation of the collateral policy of a commercial bank. In: Financial management: theory and practice, 2007, p. 152-158 [in Russian].

17. Property Industry Alliance (PIA) Long-term Value Working Group, Commercial Real Estate Finance Council Europe (CREFC Europe) and Investment Property Forum (IPF), 30 June 2017.

18. Ordin ECO/805/2003, de 09/04/2003. Disponibil: https://www.boe.es/buscar/act.php?id=BOE-A-2003-7253 